University of Nebraska - Lincoln

DigitalCommons@University of Nebraska - Lincoln

8-3-2006

\title{
Soil Microbial Biomass Relationships with Organic Matter Fractions in a Nebraska Corn Field Mapped using Apparent Electrical Conductivity
}

\author{
Maria S. Grigera \\ University of Nebraska-Lincoln \\ Rhae A. Drijber \\ University of Nebraska-Lincoln, rdrijber1@unl.edu \\ Kent M. Eskridge \\ University of Nebraska-Lincoln, keskridge1@unl.edu \\ Brian J. Wienhold \\ University of Nebraska-Lincoln, Brian.Wienhold@ars.usda.gov
}

Follow this and additional works at: https://digitalcommons.unl.edu/usdaarsfacpub

Grigera, Maria S.; Drijber, Rhae A.; Eskridge, Kent M.; and Wienhold, Brian J., "Soil Microbial Biomass Relationships with Organic Matter Fractions in a Nebraska Corn Field Mapped using Apparent Electrical Conductivity" (2006). Publications from USDA-ARS / UNL Faculty. 1221.

https://digitalcommons.unl.edu/usdaarsfacpub/1221

This Article is brought to you for free and open access by the U.S. Department of Agriculture: Agricultural Research Service, Lincoln, Nebraska at DigitalCommons@University of Nebraska - Lincoln. It has been accepted for inclusion in Publications from USDA-ARS / UNL Faculty by an authorized administrator of DigitalCommons@University of Nebraska - Lincoln. 


\title{
Soil Microbial Biomass Relationships with Organic Matter Fractions in a Nebraska Corn Field Mapped using Apparent Electrical Conductivity
}

\author{
María S. Grigera, Rhae A. Drijber, Kent M. Eskridge, and Brian J. Wienhold*
}

\begin{abstract}
Soils exhibit spatial variability in their properties. One approach for delineating field-scale variability involves mapping the variation in apparent soil electrical conductivity (ECa). The objectives of this study were to evaluate the physical and chemical soil characteristics that define ECa classification and the association of specific soil microbiological communities with these soil properties. In May 2003, ECa was measured in a field in Buffalo County, Nebraska, and processed to create four ECa zones based on ranges of horizontal and vertical ECa measurements using unsupervised classification. Soil properties $(0-90 \mathrm{~cm})$ that showed higher correlations with vertical ECa included total C $(r=0.87)$, clay $(r=0.83)$, total dissolved solids $(r=0.68)$, and depth of topsoil $(r=0.70)$. These properties influence soil water availability in this field. Soil microbial groups were correlated with different soil $\mathrm{C}$ fractions in the 0 - to $15-\mathrm{cm}$ depth and were similar across ECa zones. Bacterial $(r=0.85)$ and actinomycetes $(r=$ 0.71) biomarker concentrations were more highly correlated with fine particulate organic matter (POM) than coarse POM (bacteria $r=0.69$ and actinomycetes $r=0.48)$. In contrast, fungal $(r=0.77)$ and mycorrhizal $(r=0.48)$ biomarker concentrations were correlated only with coarse POM. Given current knowledge of the spatial distribution of POM and aggregates, we hypothesize that microorganisms are also spatially distributed and that fungal groups are closely associated with coarse POM early in the growing season.
\end{abstract}

$\mathrm{S}$ UCCESSFUL IMPLEMENTATION of site-specific management requires an understanding of how variation in physical and chemical soil properties affects nutrient and water availability and ultimately crop production in a field. Intensive soil sampling may provide the necessary information on soil fertility, water retention capacity, and other relevant soil properties that define potential productivity, but this approach is expensive and labor intensive (Kitchen et al., 1999). Apparent soil electrical conductivity (ECa) sensors have been used for delineating soil variability. Soil ECa is affected by salinity, texture, cation exchange capacity, and moisture content (Rhoades and Corwin, 1990). Soil classification

M.S. Grigera and R.A. Drijber, Dep. of Agronomy and Horticulture, Univ. of Nebraska, Lincoln, NE 68583; K.M. Eskridge, Dep. of Statistics, Univ. of Nebraska, Lincoln, NE 68506; B.J. Wienhold, USDAARS, Soil and Water Conservation Research Unit, Lincoln, NE 68583. Contribution of USDA-ARS and Univ. of Nebraska-Lincoln. Journal Ser. No. 15034. USDA-ARS, Northern Plains Area, is an equal opportunity/affirmative action employer, and all agency services are available without discrimination. Mention of commercial products and organizations in this paper is solely to provide specific information. It does not constitute endorsement by USD-ARS over other products and organizations not mentioned. Received 3 Oct. 2005. *Corresponding author (bwienhold1@unl.edu).

Published in Soil Sci. Soc. Am. J. 70:1480-1488 (2006).

Soil Biology \& Biochemistry

doi:10.2136/sssaj2005.0331

(c) Soil Science Society of America

677 S. Segoe Rd., Madison, WI 53711 USA using ECa provides an effective basis for delineating interrelated physical, chemical, and biological soil attributes important to crop productivity and ecological sustainability (Kitchen et al., 1999; Johnson et al., 2001; Wienhold and Zhang, 2001; Eigenberg et al., 2002). Measurements of ECa are a good estimate of topsoil thickness and may be used to diagnose potential rooting and water-related problems affecting crop production (Kitchen et al., 1999).

Spatial variability in crop production within a field may affect soil biota through variation in crop residue production. Soil properties are also influenced by the diverse physical and chemical properties of organic matter (OM) in soil (Baldock and Nelson, 1999). Soil OM provides the chemical energy and nutrients for soil microorganisms. As crop residue decomposes, the resulting soil OM contributes to ion exchange, soil structural stability, water retention, and soil thermal properties important to soil resilience. Each pool of soil OM contributes differently to these various functions (Baldock and Skjemstad, 1999). Particulate organic matter (POM) consists of partially decomposed plant residues and forms the first intermediate pool in the decomposition process between crop residue and humified $\mathrm{OM}$ (Gregorich and Janzen, 1996). The extent to which OM progresses through the different stages of decomposition depends on the presence of protection mechanisms capable of enhancing biological stability (Baldock and Skjemstad, 2000). The decomposition of plant residues and the dynamics of POM are directly related to soil aggregate formation and $\mathrm{C}$ stabilization in relatively undisturbed systems (Gale et al., 2000). Long term studies showed that the amount of plant $\mathrm{C}$ retained in a soil was proportional to soil clay content (Ladd et al., $1985)$ and the mean residence time was also correlated with the specific surface area of the soil minerals (Saggar et al., 1996). The presence of clay particles in soil provides the surface area onto which OM may be adsorbed (Baldock and Skjemstad, 2000) and may also provide protection for microorganisms (Skene et al., 1996). In a recent study, the stabilizing effect of clay on soil microbial biomass was even greater than that for humus (Müller and Höper, 2004). In addition to clays, multivalent cations and other nutrients affect the biological stability of OM in soils (Oades, 1988; van Veen et al., 1989; Nelson et al., 1996; Baldock and Skjemstad, 2000).

Soil microbial communities respond to changes in the soil environment. Drijber et al. (2000) compared soil microbial communities in soils under mixed prairie sod with those in soil cropped to wheat or left fallow. They

Abbreviations: ECa, apparent soil electrical conductivity; FAMEs, fatty acid methyl esters; OM, organic matter; POM, particulate organic matter; TDS, total dissolved solids. 
found that during the wheat cycle the composition of the soil microbial community was influenced mostly by inputs from wheat, whereas during fallow it responded to physicochemical differences in the soil resulting from tillage. Zymogenous microorganisms (opportunists that grow immediately after the addition of a readily decomposable organic substrate) feeding on easily decomposable OM may adapt quickly (within days) to the availability of substrate (Müller and Höper, 2004). Degens (1998) determined that microbial functional diversity in soils, measured as catabolic potential, was influenced by the addition of different types of organic C. Beare et al. (1992) concluded that when plant residue is incorporated into the soil, microenvironments are created that can strongly influence the composition of decomposer communities by changing the amount and the distribution of substrates and consumers. Thus, selected groups of soil microorganisms are likely to govern the transformations of the different labile OM pools, and the rate at which each OM pool responds to changes in management or other perturbations varies considerably between soil types and according to the nature of the organic inputs (Bending et al., 2000).

Soil microbial communities influence nutrient cycling and aggregation processes, although it is important to determine to what extent environmental and edaphic factors govern microbial communities. Phospholipid fatty acid profiles showed differences in community composition that were consistent with differences in organic $\mathrm{C}$ input under organic and conventional systems (Bossio et al., 1998). They also found that soil type was the most important determinant of microbial communities due to the influence of clay content and aeration. Schutter and Dick (2000) found that fatty acid methyl esters (FAMEs) profiles were able to separate soils differing in texture and total organic $\mathrm{C}$ content. The objectives of this study were to identify the soil physical and chemical properties influencing ECa in this field and to determine whether variation in these properties influenced the composition of soil microbial communities.

\section{MATERIALS AND METHODS}

\section{Experimental Site}

The field study was conducted during 2003 near Shelton NE $\left(40^{\circ} 45^{\prime} 01^{\prime \prime} \mathrm{N}, 98^{\circ} 46^{\prime} 01^{\prime \prime} \mathrm{W}\right)$. Soils at the site are Hord silt loam (Fine-silty, mixed mesic Pachic Argiustoll, 0-1\% slope) and a Blendon loam (Coarse-loamy, mixed mesic Pachic Haplustoll, $0-1 \%$ slope). The Hord series are soils developed on loesscapped alluvial stream terraces of the Platte and Wood River valleys, formed in silty alluvium or in loess. The Blendon series are soils formed on stream terraces along the Platte and South Loup Rivers. They are underlain by mixed sand and gravel along the Platte River and by medium and coarse sand along the South Loup River. Land leveling activities were performed on portions of the field around 1960 to facilitate furrow irrigation (J.S. Schepers, personal communication, 2005). Continuous corn (Zea mays L.) has been cropped since 1990 under conventional disk-tillage with furrow irrigation and since 1996 under disk and row cultivation with sprinkler irrigation. Before planting $168 \mathrm{~kg} \mathrm{~N} \mathrm{ha}^{-1}$ as urea ammonium nitrate solution was incorporated with a field cultivator. Corn (Pioneer 31B51)

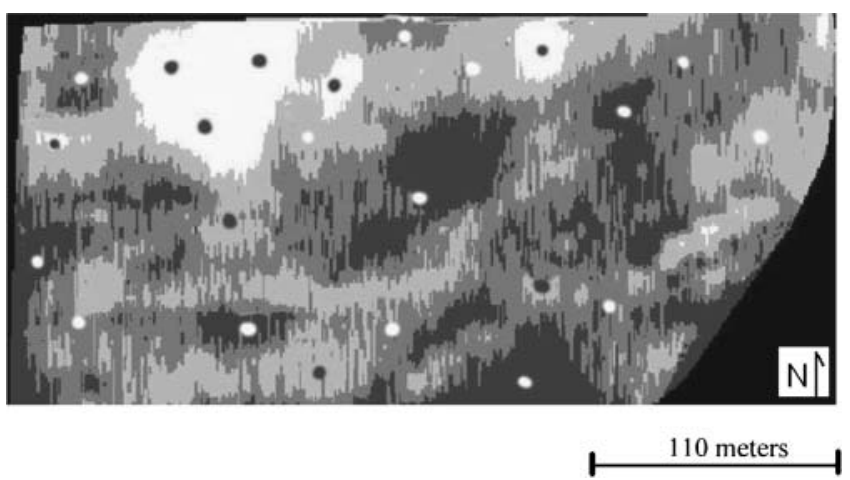

Fig. 1. Four ECa classes and location of sampling sites (circles) in each class at the Buffalo Co., NE study site. $\square: 19-20 \mathrm{dS} \mathrm{m}^{-1}$; $\square: 21-22$ dS m ${ }^{-1} ; \square:$ 23-25 dS m ${ }^{-1} ; \square: 28-35 \mathrm{dS} \mathrm{m}^{-1}$.

was planted on 16 May 2003 with $13.1 \mathrm{~kg} \mathrm{~N}^{-1}$ and $19.46 \mathrm{~kg} \mathrm{P}$ $\mathrm{ha}^{-1}$ as diammonium phosphate applied adjacent to the seed. Stand density was 71605 plants $\mathrm{ha}^{-1}$, and field average yield was $12.9 \mathrm{Mg} \mathrm{ha}^{-1}$ at $155 \mathrm{~g} \mathrm{~kg}^{-1}$ moisture content.

\section{Field Mapping}

In May 2003, ECa was measured with an EM 38 dual dipole conductance meter (Geonics Ltd., Mississauga, Ontario, Canada) pulled behind an all-terrain vehicle. Data were logged in vertical mode $(\sim 0-90 \mathrm{~cm})$ and horizontal mode $(0-30 \mathrm{~cm})$ at 1 -s intervals (every $2 \mathrm{~m})$ and georeferenced using a differential global positioning system receiver (Trimble Navigation, Sunnyvale, CA) mounted near the EM38 sensor. The data collected in this 7.3-ha field were processed using ERDAS Imagine (ERDAS Inc., Atlanta, GA) to create four ECa classes based on ranges of EC measurements using unsupervised classification (ERDAS, 1997) (Johnson et al., 2001). Briefly, unsupervised classification identifies statistically similar clusters and combines them into classes (Fig. 1, Table 1). Six locations in each ECa class were randomly selected for soil sampling.

\section{Soil Sampling and Analysis}

Soil samples were collected during the V6 stage of corn (Ritchie et al., 1997) on 20 June 2003. Ten soil cores (2-cm diam., 0 - to $15-\mathrm{cm}$ depth) were randomly taken from the furrow at each location in an area of $6 \mathrm{~m}^{2}$ (Fig. 1). The composite soil samples were transported in a cooler to the laboratory and

Table 1. Range of values of ECa vertical and horizontal readings, topsoil depth, and variables studied in the $0-$ to $90-\mathrm{cm}$ depth.

\begin{tabular}{|c|c|c|c|c|c|c|c|c|}
\hline Class & ECav & ECah & $\begin{array}{l}\text { Topsoil } \\
\text { depth }\end{array}$ & Bray $P$ & $\begin{array}{c}\text { Clay } \\
\text { content }\end{array}$ & TDS & TC & $\mathbf{T N}$ \\
\hline & $-\mathrm{dS}$ & ${ }^{-1}-$ & cm & $\mathrm{kg} \mathrm{ha}^{-1}$ & ${ }^{-}$ & Mg ha & -1 & \\
\hline \multicolumn{9}{|c|}{ - } \\
\hline Max & 20 & 15 & 45 & 716 & 2031 & 2.0 & 131 & 15 \\
\hline Min & 19 & 14 & 35 & 78 & 1474 & 1.7 & 107 & 13 \\
\hline \multicolumn{9}{|l|}{ II } \\
\hline Max & 22 & 17 & 42 & 139 & 2290 & 2.5 & 146 & 16 \\
\hline Min & 21 & 16 & 28 & 40 & 1482 & 1.8 & 88 & 11 \\
\hline \multicolumn{9}{|l|}{ III } \\
\hline Max & 25 & 20 & 55 & 236 & 2561 & 2.5 & 165 & 17 \\
\hline Min & 23 & 19 & 30 & 28 & 1722 & 2.0 & 116 & 13 \\
\hline \multicolumn{9}{|l|}{ IV } \\
\hline Max & 35 & 26 & 62 & 328 & 2922 & 3.1 & 204 & 19 \\
\hline Min & 28 & 22 & 37 & 33 & 2183 & 2.1 & 167 & 16 \\
\hline
\end{tabular}

Bray $P=$ extractable P; ECa(h) $=$ ECa horizontal readings; $\mathbf{E C a}(v)=$ ECa vertical readings; $T C=$ total $C ;$ TDS $=$ total dissolved solids; $T N=$ total $N$. 
passed through a 4-mm sieve to remove visible organic residues, thoroughly mixed, and divided in two subsamples. One subsample was stored at $-20^{\circ} \mathrm{C}$ for microbial biomass and fatty acid analysis. The other subsample was passed through 2-mm sieve, air-dried, and analyzed for clay content (Kettler et al., 2001), total OM and POM (0.05-2 mm) by weight losson-ignition (Cambardella et al., 2001), total C, and $\mathrm{N}$ analyzed with a Carlo Erba NA 100 (CE Elantech, Lakewood, NJ) (Schepers et al., 1989), $\mathrm{pH}$, and electrical conductivity $\left(\mathrm{EC}_{(1: 1)}\right)$ in 1:1 soil/water slurry (Smith and Doran, 1996). $\mathrm{NO}_{3}-\mathrm{N}$ was determined by a commercial laboratory (Brown, 1998). Soil bulk density was determined by dividing the oven dry weight of the soil by the volume of the sample before sieving. Bulk density was similar among ECa classes and the average value of $1.28 \mathrm{Mg} \mathrm{m}^{-3}$ was used to convert the concentration data to volumetric data.

After harvest, a soil core (5-cm diam., 0-90 cm) was collected from the center of each location using a truck-mounted hydraulic soil sampler. Topsoil depth was defined as the depth from the surface to the first change of soil color. Carbonate depth was determined by dropping a $10 \%$ hydrochloric acid solution on the soil core and measuring the distance from the soil surface to where effervescence occurred. No effervescence was observed in any of the cores. The sample was divided in four sections: 0 to 15,15 to 30,30 to 60 , and 60 to $90 \mathrm{~cm}$. Soil particle size, Bray $\mathrm{P}, \mathrm{EC}_{(1: 1)}$, total $\mathrm{C}$, and $\mathrm{N}$ of each depth increment were determined on air-dried, 2-mm sieved soil samples using methods described previously. Total dissolved solids (TDS) were estimated by multiplying the $\mathrm{EC}_{(1: 1)}$ at $25^{\circ} \mathrm{C}(\mathrm{dS}$ $\mathrm{m}^{-1}$ ) value for each depth interval by 0.64 and summing these values to obtain a TDS value for the $0-$ to $90-\mathrm{cm}$ depth (Smith and Doran, 1996).

\section{Quantification, Identification, and Classification of FAMEs}

Microbial biomass was determined as extractable lipid $\mathrm{P}$ on duplicate 1-g samples using perchloric acid digestion and determining the released phosphate by the method of Bartlett (Kates, 1986) and reported on dry weight soil basis. Microbial community structure was based on extraction of total FAMEs by mild alkaline hydrolysis. This process does not methylate free fatty Acids, but only ester-linked fatty acids (Kates, 1986; Grogan and Cronan, 1997). Briefly, 10-g soil samples were hydrolyzed using freshly prepared $0.2 \mathrm{M}$ potassium hydroxide in methanol, and the resulting FAMEs were partitioned into hexane (White et al., 1979). After saponification to release esterlinked FAMEs, methyl-nonadecanoate $\left(0.05 \mu \mathrm{g} \mu \mathrm{L}^{-1}\right)$ was added to the extract as an internal standard. Released FAMEs were separated by gas chromatography, using helium as a carrier gas, and an Ultra $2 \mathrm{HP}(50 \mathrm{~m}, 0.2 \mathrm{~mm}$ i.d., $0.33 \mu \mathrm{m}$ film thickness) capillary column. The gas chromatograph was run in split mode (44:1) with a 0.75 -min purge time. Injector and flame ionization detectors were maintained at $280^{\circ} \mathrm{C}$ and $300^{\circ} \mathrm{C}$, respectively, and oven temperature was ramped from 50 to $160^{\circ} \mathrm{C}$ at $40^{\circ} \mathrm{C} \mathrm{min}^{-1}$ and held for $2 \mathrm{~min}$, then ramped at $3^{\circ} \mathrm{C} \mathrm{min} \operatorname{mos}^{-1}$ to $300^{\circ} \mathrm{C}$ and held for $30 \mathrm{~min}$. The fatty acids were identified by retention-time and confirmed by mass spectrometry. Concentrations of FAMEs were calculated from peak areas and reported as $\mathrm{nmol} \mathrm{g}^{-1}$ soil.

Fatty acids were designated as the total number of $\mathrm{C}$ atoms followed by a colon, and the number of double bonds followed by the position of the double bond from the carboxyl end of the molecule and its cis or trans configuration (IUPAC-IUB, 1987). The prefixes $a$ and $i$ indicate antieso and iso branching, respectively; $c y$ indicates cyclopropane fatty acids, $b r$ indicates an unknown branch position, and $10 \mathrm{Me}$ indicates a methyl branch on the 10th $\mathrm{C}$ atom from the carboxyl end of the molecule. A total of 41 FAMEs were detected and identified. Those selected to represent bacterial markers were $i \mathrm{C} 15: 0$, $a \mathrm{C} 15: 0, \mathrm{C} 15: 0, i \mathrm{C} 16: 0, i \mathrm{C} 17: 0, a \mathrm{C} 17: 0, \mathrm{C} 17: 0, c y \mathrm{C} 17: 0, c y \mathrm{C} 19: 0$, and C16:1cis7. Frostegård and Bååth (1996) recommend the use of several bacterial fatty acid markers because this is likely to produce less variable results than the use of only one marker. The markers selected to represent actinomycetes were i10MeC18:0 and 10MeC18:0 (Kroppenstedt, 1985). Fungal biomarkers was represented by C18:2cis9,12 (Stahl and Klug, 1996), and arbuscular mycorrhizal biomarkers were represented by C16:1cis11 (Olsson and Johansen, 2000).

\section{Statistical Analysis}

Relationships between crop and soil components and ECa class were assessed by ANOVA for a complete randomized design with vertical and horizontal ECa class (identified using unsupervised classification) as treatment factors (Johnson et al., 2001). Analysis of variance was also performed to test for differences in physical and chemical soil properties among ECa classes. Pearson correlation analysis was conducted to assess the linear association between ECa sample means for each location and soil physicochemical and microbiological properties. All statistical analyses were performed using SAS (SAS Inst., 1999), and differences were declared significant at the 0.05 level unless stated otherwise.

\section{RESULTS AND DISCUSSION \\ Relationship of ECa Class to Soil Properties in the 0- to 90-cm Depth}

The range of vertical and horizontal ECa measurements and soil physicochemical properties are shown in Table 1. Of the physical and chemical soil properties measured, we found that clay content in Class I was lower than that observed in Class III and IV (Fig. 2a). Topsoil depth was similar for Classes I, II, and III and greater in Class IV. The increase in ECa was correlated with the amount of clay and depth of topsoil; however, the correlation coefficient between ECa and total clay was higher (Table 2). Total C content (and N, data not shown) followed the pattern of clay content in this profile (Fig. 2c) being largest in Class IV followed by Class III and smallest in Classes I and II. Total dissolved solids were lowest in Class I and largest in Class IV (Fig. 2d).

Horizontal and vertical ECa measurements were highly correlated with clay, organic C content, TDS, and topsoil depth in the 0- to $90-\mathrm{cm}$ samples (Table 2). Bray P was associated with vertical ECa but not with horizontal readings. Depth of topsoil was positively correlated with clay and $\mathrm{C}$ content. Bulk ECa readings integrated many soil properties and seem to be a useful tool for the delineation of overall soil condition (Johnson et al., 2001). The correlation among clay, total C, TDS, depth of topsoil, and ECa may represent soil properties affecting water availability to the crop. Previous studies indicated that in the central Great Plains, vertical ECa was driven by soil water content, solids in the soil solution, and clay content at the 0 - to $90-\mathrm{cm}$ depth and correlated with soil water-holding capacity (Johnson et al., 2003b). Similarly, Auerswald et al. (2001) used multivariate regression to 

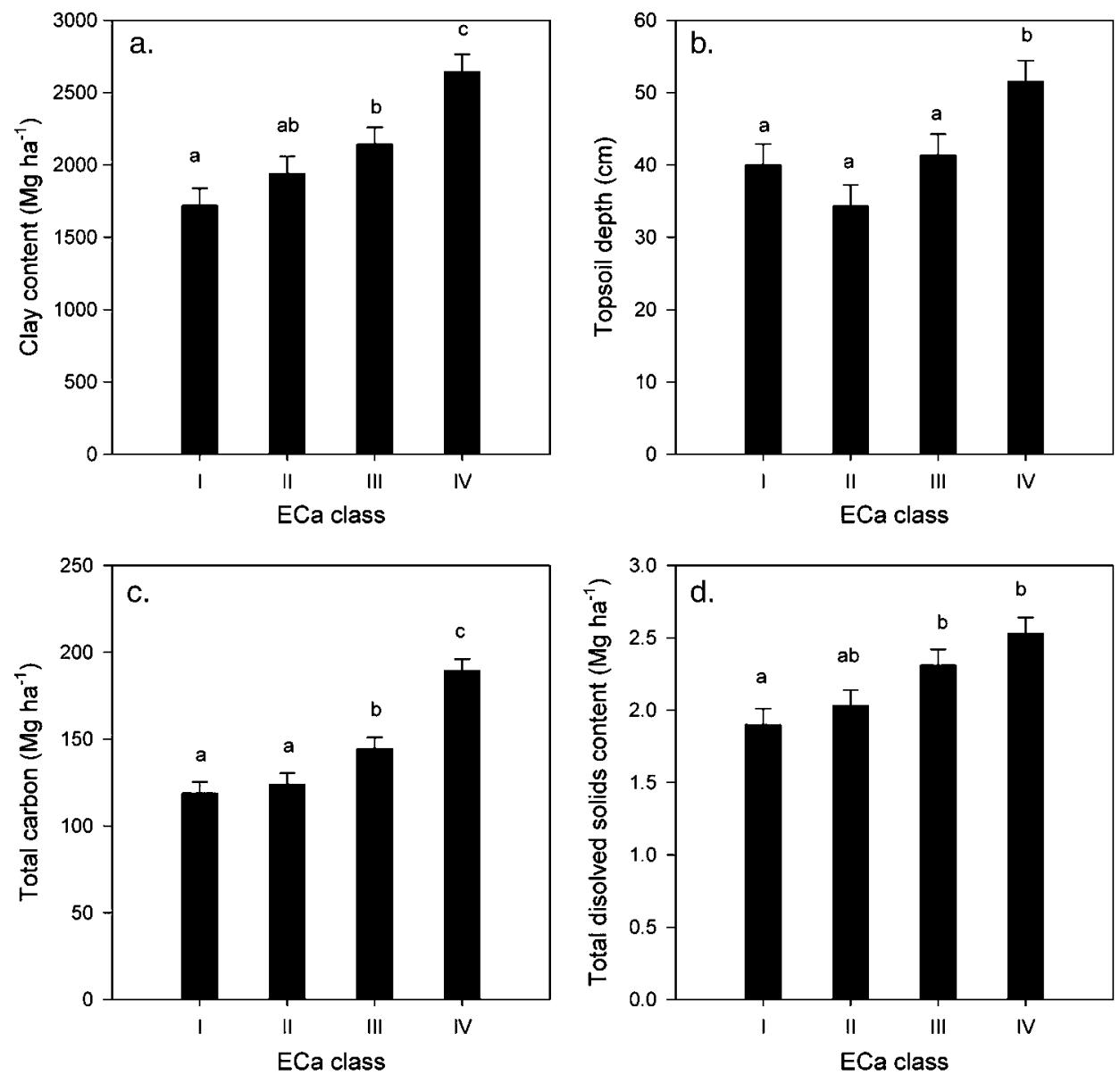

Fig. 2. Apparent electrical conductivity (ECa) classes and (a) clay content (0-90 cm), (b) total C (0-90 cm), (c) topsoil depth, and (d) total dissolved solids content $(0-90-\mathrm{cm})$. Bars followed by the same letter within ECa classes are not significantly different $(p<0.05)$. Error bars represent \pm one standard error of the mean.

determine the relationship among ECa and a number of soil properties and found that clay content, $\mathrm{EC}_{(1: 1)}$, and water content explained $84 \%$ of the variability observed in $\mathrm{ECa}$.

\section{Relationship of ECa Class to Soil Properties in the 0- to 15-cm Depth}

Although ECa seems to integrate soil properties over depth, management impacts are usually most evident in the surface soil layer. The physical, chemical, and biological soil parameters evaluated to characterize the sur- face layer $(0-15 \mathrm{~cm})$ of this field are presented in Table 3 . Soil $\mathrm{pH}$ was similar among the ECa classes with a mean value of $6.7(p=0.57)$. Simple correlation coefficients of spatially varying soil properties provide the first level of information needed to determine what factors covary with ECa. Horizontal and vertical ECa measurements were positively correlated with Bray $\mathrm{P}$ and TDS measured in the laboratory and were negatively correlated with mycorrhizal fungal biomarker concentration. No significant correlations were observed between ECa and total C, fine and coarse POM, and clay content in this surface layer (Table 3). However, there was a significant

Table 2. Correlation matrix for grain and stover yield, soil physical, and chemical properties (0-90 cm).

\begin{tabular}{|c|c|c|c|c|c|c|c|c|c|}
\hline & $\operatorname{ECa}(\mathbf{v})$ & $\operatorname{ECa}(\mathbf{h})$ & Grain & Stover & Bray $P$ & Depth & TC & Clay & TDs \\
\hline ECa(v) & 1 & & & & & & & & \\
\hline ECa(h) & $0.98 * *$ & 1 & & & & & & & \\
\hline Grain & 0.30 & 0.27 & 1 & & & & & & \\
\hline Stover & $0.62 * *$ & $0.61 * *$ & $0.54 * *$ & 1 & & & & & \\
\hline Bray P & -0.33 & $-0.43^{*}$ & $-\mathbf{0 . 1 3}$ & -0.24 & 1 & & & & \\
\hline Depth & 0.70** & $\mathbf{0 . 6 3}^{* *}$ & $\mathbf{0 . 3 0}$ & $\mathbf{0 . 6 5}$ ** & 0.10 & 1 & & & \\
\hline TC & $0.87 * *$ & $\mathbf{0 . 8 8}^{* *} *$ & 0.23 & $0.75 * *$ & -0.28 & $0.69 * *$ & 1 & & \\
\hline Clay & $\mathbf{0 . 8 3}^{* *} *$ & $0.81 * *$ & 0.17 & $0.61 * *$ & $-\mathbf{0 . 3 4}$ & 0.66** & $0.84 * *$ & 1 & \\
\hline TDS & $\mathbf{0 . 6 8} * *$ & 0.71 $* *$ & 0.13 & 0.38 & $-\mathbf{0 . 2 9}$ & 0.32 & $0.59 * *$ & $0.55 * *$ & 1 \\
\hline
\end{tabular}

Bray $P=$ extractable P; Depth $=$ topsoil depth; ECa(h) $=$ ECa horizontal readings; ECa(v) $=$ ECa vertical readings; TC $=$ total C; TDS $=$ total dissolved solids.

* Correlation between measured attributes significant at the 0.05 level.

** Correlation between measured attributes significant at the 0.01 level. 
Table 3. Correlation matrix for grain and stover yield and for soil physical and chemical properties (0-15 cm).

\begin{tabular}{|c|c|c|c|c|c|c|c|c|c|c|c|c|c|c|c|c|c|}
\hline & $\operatorname{ECa}(v)$ & $\mathbf{E C a}(\mathbf{h})$ & Grain & Stover & Clay & $\mathbf{D}_{\mathbf{b}}$ & TDS & TC & $\mathrm{N}-\mathrm{NO}_{3}$ & Bray $\mathbf{P}$ & СРОМ & FPOM & Lipid P & Bact & Actin & Мyco & Fungi \\
\hline ECa(v) & 1 & & & & & & & & & & & & & & & & \\
\hline ECa(h) & $0.98 * *$ & 1 & & & & & & & & & & & & & & & \\
\hline Grain & 0.30 & 0.27 & 1 & & & & & & & & & & & & & & \\
\hline Stover & $0.62 * *$ & $0.61 * *$ & $0.54 * *$ & 1 & & & & & & & & & & & & & \\
\hline Clay & 0.25 & 0.30 & -0.16 & 0.29 & 1 & & & & & & & & & & & & \\
\hline $\mathbf{D}_{\mathbf{b}}$ & $-\mathbf{0 . 3 3}$ & -0.36 & 0.21 & -0.16 & $-\mathbf{0 . 7 0} * *$ & 1 & & & & & & & & & & & \\
\hline TDS & $\mathbf{0 . 4 3} *$ & 0.45* & -0.11 & 0.15 & $\mathbf{0 . 5 6} * *$ & $-0.61 * *$ & 1 & & & & & & & & & & \\
\hline TC & 0.26 & 0.30 & 0.0 & 0.21 & $0.85 * *$ & $-0.63 * *$ & $0.58 * *$ & 1 & & & & & & & & & \\
\hline $\mathrm{N}-\mathrm{NO}_{3}$ & 0.12 & 0.14 & -0.01 & -0.09 & 0.12 & -0.23 & $0.61 * *$ & 0.24 & 1 & & & & & & & & \\
\hline Bray P & $\mathbf{0 . 7 9} * *$ & $0.81 * *$ & 0.17 & $0.65 * *$ & 0.37 & $-0.42 *$ & $0.56 * *$ & 0.27 & 0.17 & 1 & & & & & & & \\
\hline СРОМ & -0.60 & -0.2 & -0.24 & -0.18 & 0.21 & -0.21 & 0.30 & $0.50 *$ & 0.38 & 0.0 & 1 & & & & & & \\
\hline FPOM & 0.28 & $\mathbf{0 . 3 3}$ & -0.13 & 0.07 & $0.51 *$ & $-0.62 * *$ & $0.54 * *$ & $0.53 * *$ & 0.17 & $0.43^{*}$ & $0.47^{*}$ & 1 & & & & & \\
\hline Lipid P & 0.27 & 0.34 & -0.22 & 0.08 & $0.66 * *$ & $-0.66^{* * *}$ & $0.65 * *$ & $0.72 * *$ & 0.30 & $0.46^{*}$ & $0.67 * *$ & $0.87 * *$ & 1 & & & & \\
\hline Bact & 0.22 & 0.29 & -0.13 & 0.10 & $0.68 * *$ & $-0.59 * *$ & $0.61 * *$ & $\mathbf{0 . 7 3} * *$ & 0.28 & $0.40 \dagger$ & $0.69 * *$ & $0.85^{* *}$ & $0.96 * *$ & 1 & & & \\
\hline Actin & 0.11 & 0.18 & -0.25 & -0.40 & $0.74 * *$ & $-0.61 * *$ & 0.71** & $0.72 * *$ & $0.40 \dagger$ & 0.34 & $0.47^{*}$ & $0.71 * *$ & $0.82 * *$ & $\mathbf{0 . 8 8}^{* * *}$ & 1 & & \\
\hline Мусо & $-0.45^{*}$ & $-0.43^{*}$ & -0.29 & $-0.57 * *$ & 0.06 & 0.06 & -0.07 & 0.18 & 0.17 & $-\mathbf{0 . 5 3}^{* *}$ & $0.48^{*}$ & 0.25 & 0.29 & 0.37 & 0.34 & 1 & \\
\hline Fungi & -0.37 & -0.37 & -0.31 & $-0.50 *$ & 0.0 & -0.04 & 0.21 & 0.24 & $0.46^{*}$ & -0.35 & $\mathbf{0 . 7 7} * *$ & 0.25 & $0.43 *$ & $0.44 *$ & 0.35 & $\mathbf{0 . 7 4} * *$ & 1 \\
\hline
\end{tabular}

Actin $=$ actinomycetes markers $($ i10MeC18:0, 10MeC18:0); Bact $=$ bacterial markers $(i C 15: 0, a C 15: 0$, C15:0, $i$ C16:0, iC17:0, aC17:0, C17:0, cyC17:0, cyC19:0,C16:1 cis7); $\mathrm{D}_{\mathrm{b}}=$ bulk density; Bray $P=$ extractable P; CPOM = coarse particulate organic matter (0.5-2 mm); ECav $=$ ECa vertical readings; ECah = ECa horizontal readings; FPOM = fine particulate organic matter $(0.053-0.5 \mathrm{~mm})$; Fungi $=$ fungal marker $(\mathrm{C18}$ :2cis9,12); Lipid P $=$ total microbial biomass; Myco $=$ mycorrhizal marker (C16:1cis11); TC $=$ total C, TDS $=$ total dissolved solids.

* Correlation between measured attributes significant at the 0.05 level.

$* *$ Correlation between measured attributes significant at the 0.01 level.

$\dagger$ Correlation between measured attributes significant at the 0.06 level.

relationship observed between total $\mathrm{C}$, POM, lipid $\mathrm{P}$, and the individual microbial pools (fungi and bacteria biomarker concentrations) (Table 3).
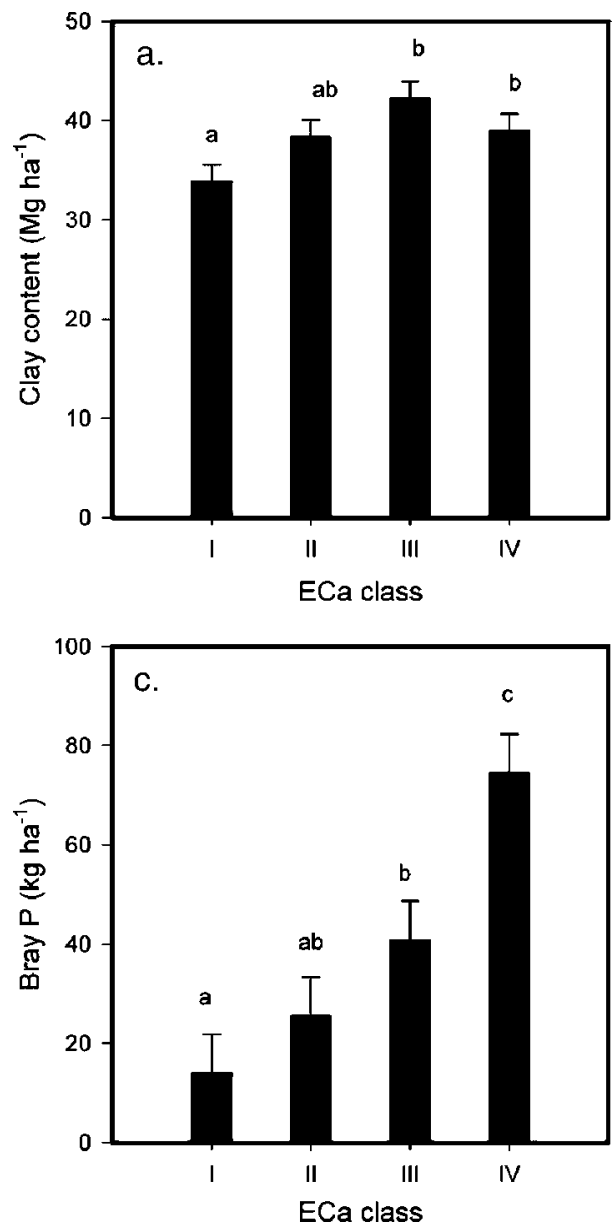

Total C (Fig. 3b) and the different fractions of POM (Fig. 3d) in the $0-$ to $15-\mathrm{cm}$ depth followed the same distribution as clay content (Fig. 3a) with an increase in
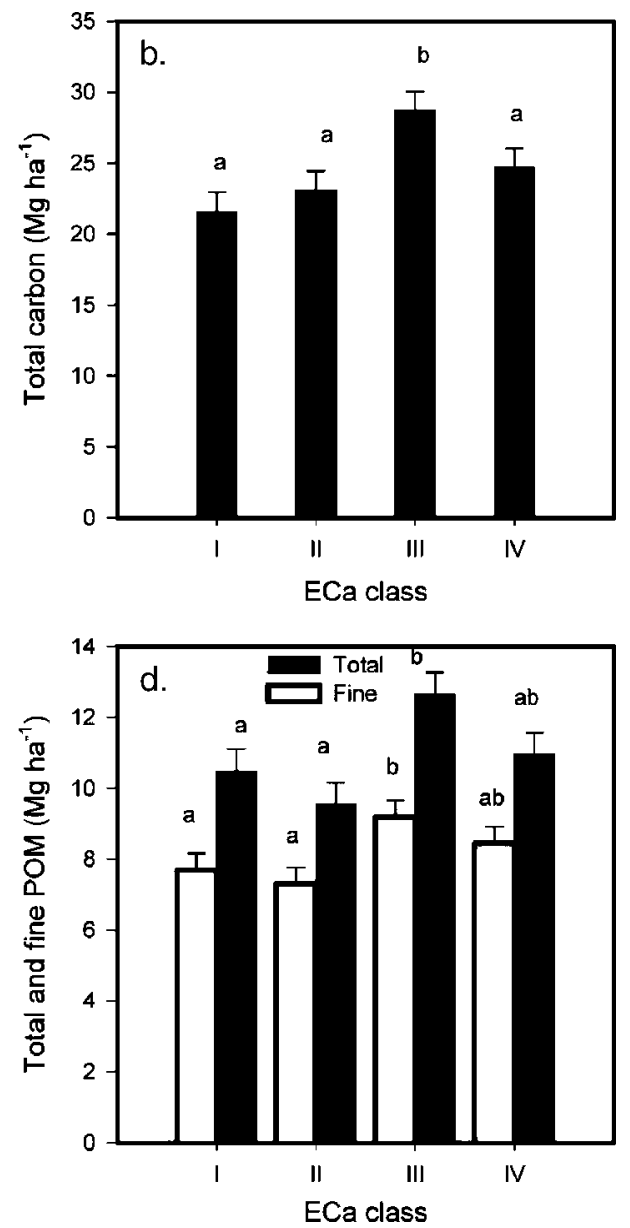

Fig. 3. Apparent electrical conductivity (ECa) classes and (a) clay content $(0-15 \mathrm{~cm})$, (b) total $\mathrm{C}(0-15 \mathrm{~cm})$, (c) extractable $P(0-15 \mathrm{~cm})$ and (d) total and fine POM (0-15 cm). Bars followed by the same letter within ECa classes are not significantly different $(p<0.05)$. Error bars represent \pm one standard error of the mean. 
ECa Class III. In contrast, Bray $\mathrm{P}$ in the 0- to $15-\mathrm{cm}$ depth (Fig. 3c) followed the same trend as the $0-$ to $90-\mathrm{cm}$ variables. Thus, among the physical, chemical, and biological soil properties in the 0 - to $15-\mathrm{cm}$ depth, clay content seemed to influence the size of the $\mathrm{C}$ pools of this stratum. The amount of clay in this surface layer increased as ECa increased for the first three ECa classes but was less than expected in ECa IV likely due to land leveling activities altering texture in this part of the field (Fig. 3a). This resulted in no correlation between ECa and clay content in the $0-$ to $15-\mathrm{cm}$ depth (Table 3 ). Mueller et al. (2003) found stronger correlations for horizontal than for vertical ECa measurements with chemical soil properties, clay content, and volumetric water content. These authors found that deep EC readings were similarly affected by the variability in ECa at the surface $(0-30 \mathrm{~cm})$ and subsurface $(30-90 \mathrm{~cm})$ layers. Our results also showed a high correlation between horizontal and vertical ECa (Table 2); however, there was dissimilar pattern in clay and $\mathrm{C}$ distribution with ECa class when comparing the $0-$ to $90-\mathrm{cm}$ and $0-$ to 15-cm depths (data not shown). The different response of ECa to soil characteristics reported by Mueller et al. (2003) may be due to differences in parent material and soil water content in that study.

Fine POM was negatively correlated with bulk density and positively correlated with TDS, total C, and Bray P, whereas coarse POM was somewhat correlated with $\mathrm{NO}_{3}-\mathrm{N}(r=0.38, p=0.07)$ (Table 3$)$. These results may indicate a linkage with crop biomass production, size of the POM fraction, and fertility status of this soil. The relationship between $\mathrm{POM}$ and chemical soil properties important to OM cycling include deposition of plant residues and roots (coarse POM) and microbial residues produced during decomposition (Baldock and Skjemstad, 2000). Fine POM was also correlated with the amount of clay, and this relationship is likely determined by the amount of fine mineral particles in the surface layer and the physical and chemical protection of different $\mathrm{C}$ pools by clay particles (Baldock and Nelson, 1999). Wander and Bollero (1999) found that POM was the most sensitive indicator of soil management practices contributing to soil quality in Illinois. They also found that biological and physical aspects of soils were the properties most altered by agronomic practices. Under dryland conditions, Johnson et al. (2001) found that POM, total C, and microbial biomass $\mathrm{C}$ were negatively correlated with ECa measurements.

Bray $\mathrm{P}$ increased as ECa readings increased (Fig. 3c and Table 3). An aerial photo used in the soil survey (Buller et al.,1974) showed that the portion of the field that comprises ECa Class IV was segregated by fencing under different management. Specific management practices for this part of the field are not known, but manure applications or different fertilizer practices than the rest of the field may explain the differences. Heiniger et al. (2003) attributed part of the success of using ECa to measure $\mathrm{P}$ concentration in the field to salinity imparted by manure. Furthermore, ECa maps were able to differentiate rates of compost, manure, and commercial fertilizer additions to a corn field (Eigenberg and
Nienaber, 1998). Others have correlated ECa to tillage and cropping patterns (Clay et al., 2001; Johnson et al., 2003a).

Grain and stover yield were correlated variables. Vertical and horizontal ECa and Bray P $(0-15 \mathrm{~cm})$ were correlated with stover yield (Table 3 ). Stover production increased as vertical ECa increased (Stover $=3.58+$ $\left.0.11 \mathrm{ECa} ; r^{2}=0.38 ; p<0.001\right)$. However, there were no differences among classes in grain production (mean $8.5 \mathrm{Mg} \mathrm{ha}^{-1}$ ). The lack of a correlation between grain yield and ECa may be related to the high availability of water in this irrigated corn field. Under dry land conditions, Kravchenko et al. (2003) found that in years with optimum precipitation, grain yield and EC were not correlated.

\section{Relationship of Microbial Biomarkers to Particulate Organic Matter}

Lipid P, which is indicative of soil microbial biomass, was higher in ECa Classes III and IV than in Classes I and II (Fig. 4a). At this early growth stage of the crop (V6 stage), total microbial biomass in the furrow environment seems to be driven by bacterial biomarker concentration $(r=0.96)$ (Fig. 5). Bacterial and actinomycetes biomarker concentrations were highly correlated $(r=0.88)$ and increased with increasing ECa (Fig. 4b and 4c), although not significantly in all cases, mirroring that of clay and total $\mathrm{C}$ in this surface soil layer. Schutter et al. (2001) studied the soil microbial response to soil type, seasonal changes, and soil management using FAMEs. They found that FAMEs profiles were correlated with soil texture, cation exchange capacity, and $\mathrm{C}$ content in early spring. Fungal and mycorrhizal biomarker concentrations were not different among ECa classes (Fig. 4d), although mycorrhizal biomarker concentration was negatively correlated with horizontal and vertical ECa readings (Table 3). Mycorrhizal biomarker concentration was negatively correlated with ECa values (Table 3), but mean values were similar across ECa classes (Fig. 4d). Fine POM was highly correlated with bacterial and actinomycetes biomarkers, whereas coarse POM was highly correlated with fungal biomarker concentration and to a lesser extent with actinomycetes, bacterial, and mycorrhizal biomarkers (Fig. 5). Similarly, several fungal biomarkers (C18:2cis9,12 and 18:3cis6,9,12) were enriched in soils after the incorporation of winter cover crops, suggesting that the addition of these residues was important for stimulating or maintaining fungal populations over time (Schutter et al., 2001).

The positive correlation between coarse POM and the soil microbial biomarkers (Table 3, Fig. 5) suggests that fungi, bacteria, and actinomycetes use coarse POM as a source of C. Coarse POM is mainly comprised of plant residues but may contain seeds and microbial structural components, such as fungal hyphae and spores (Dalal and Mayer, 1986a, 1986b; Oades et al., 1987), indicating an early stage of decomposition and a microbial contribution, mostly fungal, to this coarse fraction (Six et al., 2001, 2004). Baldock and Skjemstad (2000) used nuclear 

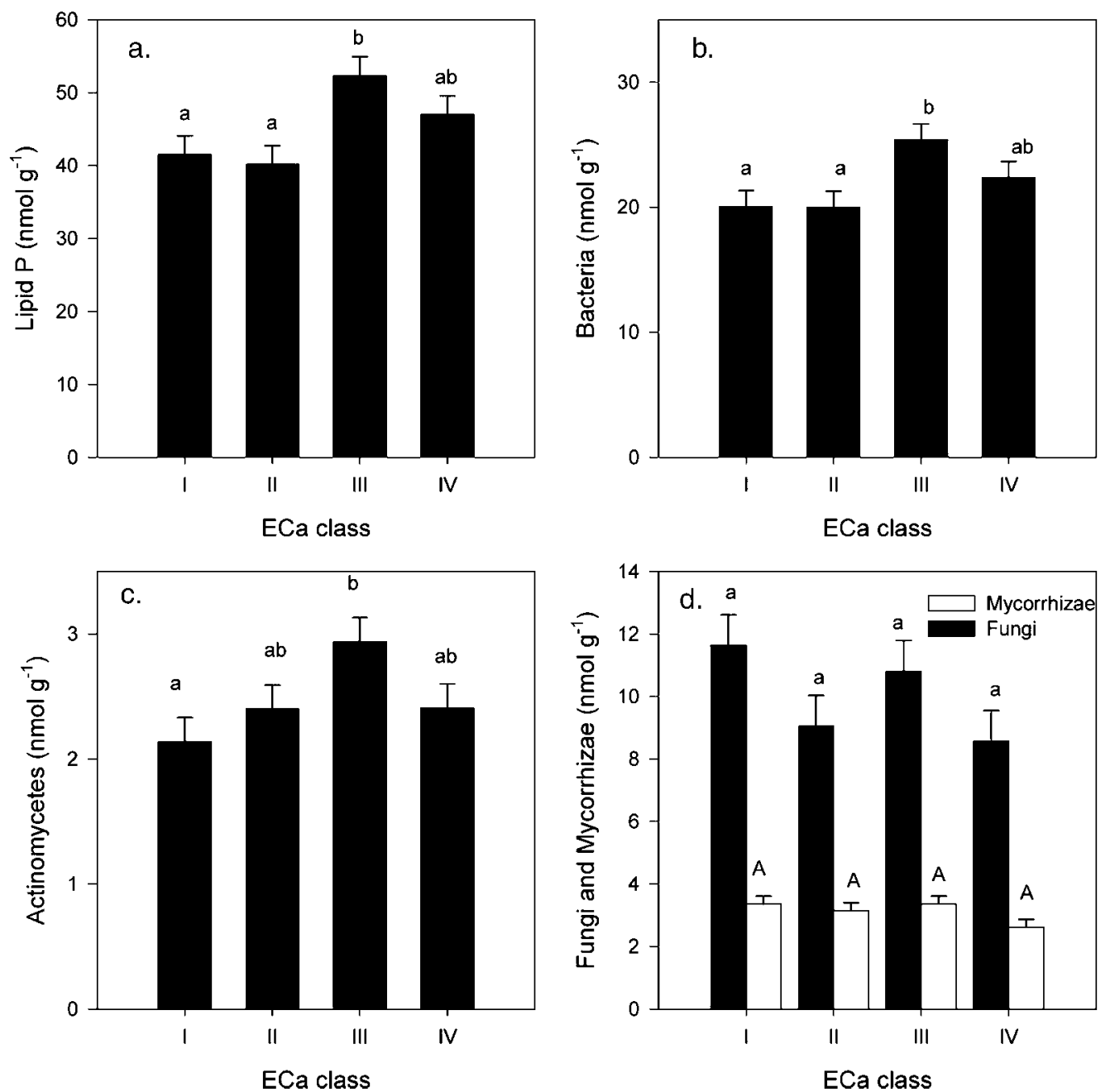

Fig. 4. Apparent electrical conductivity (ECa) classes and biological soil properties in the 0- to 15-cm depth. (a) Total microbial biomass measured as lipid P; (b) Bacteria = bacterial markers (iC15:0, aC15:0, C15:0, iC16:0, $i$ C17:0, aC17:0, C17:0, cyC17:0, cyC19:0,C16:1cis7); (c) Actinomycetes = actinomycetes markers (i10MeC18:0, 10MeC18:0); and d) Fungi = fungal marker (C18:2cis9,12) and Mycorrhizae = mycorrhizal marker (C16:1cis11). Bars followed by the same letter within ECa classes are not significantly different $(p<0.05)$. Error bars represent \pm one standard error of the mean.

magnetic resonance to analyze the structure of POM and found that it is dominated by O-alkyl structures, such as polysaccharides, which are typically found in fresh plant and microbial tissues. They identified these organic compounds as being preferentially used by soil microorganisms: a decrease in particle size being associated with the accumulation of more chemically recalcitrant structures in the $2-$ to $20-\mu \mathrm{m}$ size fraction. As plant residues decompose, lignin-degrading fungi are essential to continued decomposition; however, some bacteria can modify the nature of functional groups attached to lignin exposing more labile structures (Baldock and Skjemstad, 2000). Thus, the relationship among soil microbial biomass and the different fractions of POM reflects the decomposition dynamics and stability of $\mathrm{C}$ in the ecosystem. Our results indicate that fungal groups are closely associated with coarse POM early in the growing season.

Fine POM was correlated with clay content, but the coarse POM fraction was not (Table 3). This supports an intimate association between fine POM and the mineral fraction in this soil that enhances stabilization of soil $\mathrm{C}$ (Ladd et al., 1985). This protection of soil $\mathrm{C}$ may also be afforded through the process of aggregation. Golchin et al. (1994) suggested that during the transformation of free $\mathrm{C}$ into intra-aggregate light $\mathrm{C}$, there is a selective decomposition of easily decomposable carbohydrates (e.g., O-alkyl C) and preservation of more recalcitrant longchained C (e.g., alkyl C). During this process, POM is reduced in size and gradually becomes encrusted with clay particles and microbial products to form microaggregates (Golchin et al., 1994). Bacteria may be occluded inside these aggregates, protected from predation, and linked to this pool of POM, which is less accessible to fungal biomass. Our results support the association of bacterial and actinomycetes biomarkers with the fine POM fraction (Fig. 5, Table 3) indicating that pools of protected $\mathrm{C}$ with a slower decomposition rate might be preferentially colonized by bacteria instead of fungi.

The mycorrhizal marker was negatively correlated with Bray $\mathrm{P}$ in this surface layer (Table 3). Spore germi- 


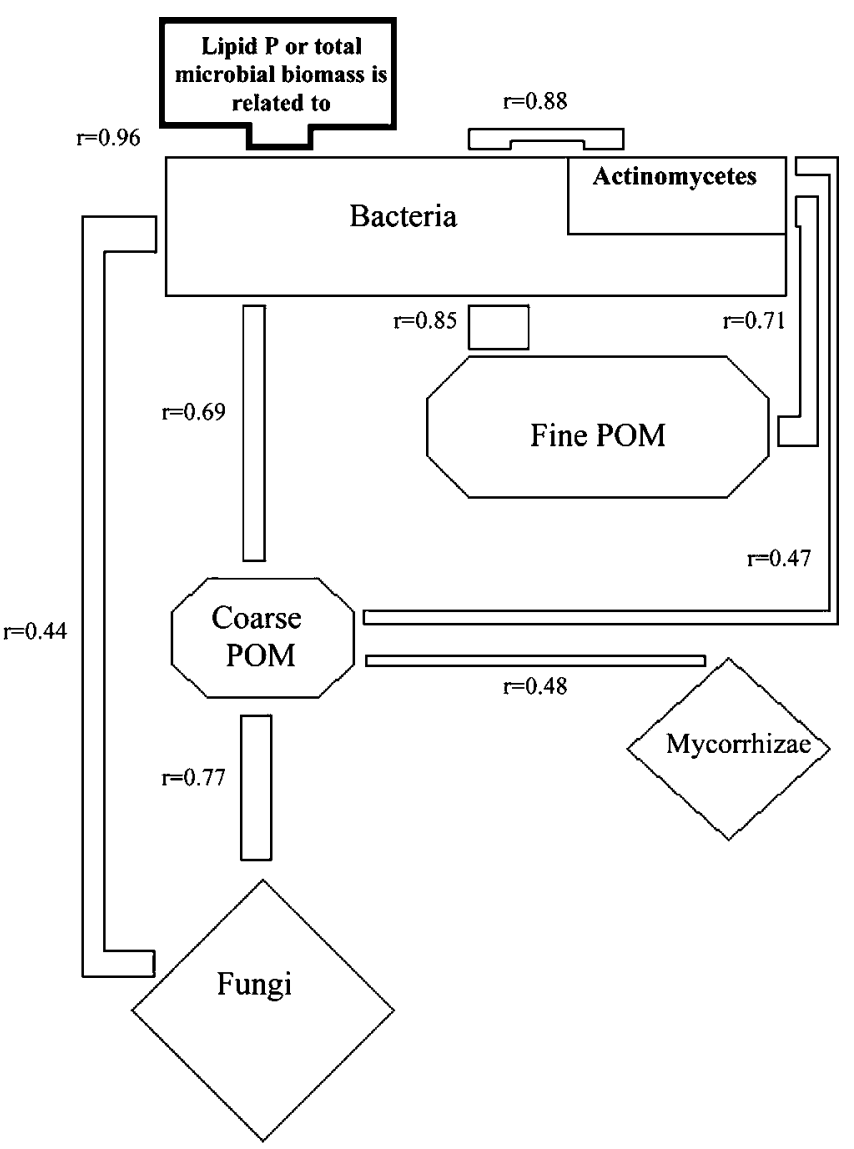

Fig. 5. Correlations among coarse and fine particulate organic matter fractions and different microbial groups during V6 stage of corn.

nation and hyphal growth of mycorrhizal fungi is known to be heavily dependent on the availability of soil $\mathrm{P}$ (De Miranda and Harris, 1994); thus, mycorrhizal biomass decreased as the availability of $P$ increased in the surface soil. Because we collected samples in the furrow environment, our study would reflect remnants of the previous year's mycorrhizal network and any new hyphae formed at this early growth stage. Although mycorrhizal fungi are important for plant $\mathrm{P}$ uptake, the significance of this role under the high fertility status of this system is uncertain.

In conclusion, ECa classes were defined by the amount of clay, organic C, and TDS in the 0 - to 90-cm depth and by the depth of topsoil. EC was an effective tool to identify soil sampling sites that represent diverse soil physicochemical properties. Soil properties measured for the shallow depth were not highly correlated with ECa, except for TDS and Bray P. Soil physicochemical characteristics evaluated in the $0-$ to $15-\mathrm{cm}$ layer are influenced by management practices and prior history of this field. Soil microbial biomass was related to total $\mathrm{C}$ and clay content in this surface layer. However, inherent soil chemical and physical properties in the $0-$ to $90-\mathrm{cm}$ depth influenced potential production of corn dry matter; hence, the amount of corn residue returned to the soil. Over time, greater residue inputs in ECa IV should result in increases in OM and microbial biomass. Thus, soil biological properties in the surface layer are ex- pected to correlate more strongly over time with ECa class. Soil microorganisms play important roles in residue decomposition, nutrient cycling, and maintenance of soil structure. Thus, knowledge of their spatial variability will lead to improved management of spatially variable fields.

\section{ACKNOWLEDGMENTS}

We thank Liz Jeske, Susan Siragusa, Susan Wagner, and Paul Koerner for laboratory assistance and field data collection. We also thank Scott Stubblefield for allowing access to his field and for his willingness to provide management input data.

\section{REFERENCES}

Auerswald, K., S. Simon, and H. Stanjek. 2001. Influence of soil properties on electrical conductivity under humid water regimes. Soil Sci. 166:382-390.

Baldock, J.A., and J.O. Skjemstad. 1999. Soil organic carbon/soil organic matter. p. 159-170. In K.I. Peverill et al. (ed.) Soil analysis: An interpretation manual. CSIRO Publishing, Melbourne, Australia.

Baldock, J.A., and J.O. Skjemstad. 2000. Role of the soil matrix and minerals in protecting natural organic material against biological attack. Org. Geochem. 31:697-710.

Baldock, J.A., and P.N. Nelson. 1999. Soil organic matter. p. D3-D18. In M.E. Summer et al. (ed.) Handbook of soil science. CRC Press, Boca Raton, FL.

Beare, M.H., R.W. Parmelee, P.F. Hendrix, and W. Cheng. 1992. Microbial and faunal interactions and effects on litter nitrogen and decomposition in agroecosystems. Ecol. Monogr. 62:569-591.

Bending, G.D., C. Putland, and F. Rayns. 2000. Changes in microbial community metabolism and labile organic matter fractions as early indicators of the impact of management on soil biological quality. Biol. Fertil. Soils 31:78-84.

Bossio, D.A., K.M. Scow, and K.J. Graham. 1998. Determinants of soil microbial communities: Effects of agricultural management, season, and soil type on phospholipids fatty acid profiles. Microb. Ecol. 36:1-12.

Bray, R.H., and L.T. Kurtz. 1945. Determination of total, organic, and available forms of phosphorus in soils. Soil Sci. 59:39-45.

Brown, J.R. 1998 (ed.) Recommended chemical soil test procedures for the north central region. North Central Region Research Publication No. 221 (Revised). Missouri Agricultural Experiment Station SB 1001, Columbia, MO.

Buller, L.L., R.S. Pollock, R.A. Boccheciamp, C.L. Hammond, H. Hill, and J.A. Elder. 1974. Soil survey of Buffalo County, Nebraska USDA-SCS. U.S. Gov. Print. Office, Washington, DC.

Cambardella, C.A., A.M. Gajda, J.W. Doran, B.J. Wienhold, and T.A. Kettler. 2001. Estimation of particulate and total organic matter by weight loss on ignition. p. 349-359. In R. Lal et al. (ed.) Assessment methods for soil carbon. CRC Press, Boca Raton, FL.

Clay, D.E., J. Chang, D.D. Malo, C.G. Carlson, C. Reese, S.A. Clay, M Ellsbury, and B. Berg. 2001. Factors influencing spatial variability of soil apparent electrical conductivity. Commun. Soil Sci. Plant Anal. 32:2993-3008.

Dalal, R.C., and R.J. Mayer. 1986a. Long term trends in fertility of soils under continuous cultivation and cereal cropping in southern Queensland. III: Distribution and kinetics of soil organic carbon in particle-size fractions. Aust. J. Soil Res. 24:293-300.

Dalal, R.C., and R.J. Mayer. 1986b. Long term trends in fertility of soils under continuous cultivation and cereal cropping in southern Queensland. IV: Loss of organic carbon from different density functions. Aust. J. Soil Res. 24:301-309.

Degens, B.P. 1998. Microbial functional diversity can be influenced by the addition of simple organic substrates to soil. Soil Biol. Biochem. 30:1981-1988.

De Miranda, J.C.C., and P.J. Harris. 1994. Effects of soil phosphorous on spore germination and hyphal growth of arbuscular mycorrhizal fungi. New Phytol. 128:103-108.

Drijber, R.A., J.W. Doran, A.M. Parkhurst, and D.J. Lyon. 2000. Changes in soil microbial community structure with tillage un- 
der long-term wheat-fallow management. Soil Biol. Biochem. 32: 1419-1430.

Eigenberg, R.A., J.W. Doran, J.A. Nienaber, R.B. Ferguson, and B.L. Woodbury. 2002. Electrical conductivity monitoring of soil condition and available $\mathrm{N}$ with animal manure and a cover crop. Agric. Ecosyst. Environ. 88:183-193.

Eigenberg, R.A., and J.A. Nienaber. 1998. Electromagnetic survey of cornfield with repeated manure applications. J. Environ. Qual. 27: 1511-1515.

ERDAS. 1997. ERDAS field guide. ERDAS, Inc., Atlanta, GA.

Frostegård, A., and E. Bååth. 1996. The use of phospholipid fatty acid analysis to estimate bacterial and fungal biomass in soil. Biol. Fertil. Soils 22:9-65.

Gale, W.J., C.A. Cambardella, and T.B. Bailey. 2000. Root-derived carbon and the formation and stabilization of aggregates. Soil Sci. Soc. Am. J. 64:201-207.

Golchin, A., J.M. Oades, J.O. Skjemstad, and P. Clarke. 1994. Study of free and occluded particulate organic matter in soils by solid state ${ }^{13} \mathrm{C}$ CP/MAS NMR spectroscopy and scanning electron microscopy. Aust. J. Soil Res. 32:285-309.

Gregorich, E.G., and H.H. Janzen. 1996. Storage of soil carbon in the light fraction and macroorganic matter. p. 167-190. In M.R. Carter and B.A. Stewart (ed.) Structure and organic matter storage in soils. Lewis Publ., CRC Press, Boca Raton, FL.

Grogan, D.W., and J.E. Cronan, Jr. 1997. Cyclopropane ring formation in membrane lipids of bacteria. Microbiol. Mol. Biol. Rev. 61: 429-441.

Heiniger, R.W., R.G. McBride, and D.E. Clay. 2003. Using soil electrical conductivity to improve nutrient management. Agron. J. 95: $508-519$.

IUPAC-UIB. 1987. The nomenclature of lipids. J. Lipid Res. 19:114-128.

Johnson, C.K., J.W. Doran, H.R. Duke, B.J. Wienhold, K.M. Eskridge, and J.F. Shanahan. 2001. Field-scale electrical conductivity mapping for delineating soil condition. Soil Sci. Soc. Am. J. 65:1829-1837.

Johnson, C.K., K.M. Eskridge, B.J. Wienhold, J.W. Doran, G.A. Peterson, and G.W. Buchleiter. 2003a. Using electrical conductivity classification and within-field variability to design field-scale research. Agron. J. 95:602-613.

Johnson, C.K., D.A. Mortensen, B.J. Wienhold, J.F. Shanahan, and J.W. Doran. 2003b. Site-specific management zones based on soil electrical conductivity in a semiarid cropping system. Agron. J. 95:303-315.

Kates, M. 1986. Techniques of lipidology: Isolation, analysis and identification of lipids. p. 123-127. In R.H. Burdon and P.H. van Kippenberg (ed.) Laboratory techniques in biochemistry and molecular biology, Vol. 3, Part 2. Elsevier, New York.

Kettler, T.A., J.W. Doran, and T.L. Gilbert. 2001. A simplified method for soil particle size determination to accompany soil quality analyses. Soil Sci. Soc. Am. J. 65:849-852.

Kitchen, N.R., K.A. Sudduth, and S.T. Drummond. 1999. Soil electrical conductivity as a crop productivity measure for claypan soils. J. Prod. Agric. 12:607-617.

Kravchenko, A.N., K.D. Thelen, and N.R. Miller. 2003. Relationship among crop grain yield, topography, and soil electrical conductivity studied with cross-correlograms. Agron. J. 95:1132-1139.

Kroppenstedt, R.M. 1985. Fatty acid and menaquinon analysis of actinomycetes and related organisms. p. 173-199. In M. Goodfellow and D.E. Minnikin (ed.) Chemical methods in bacterial systematics. Academic Press, London.

Ladd, J.N., M. Amato, and J.M. Oades. 1985. Decomposition of plant material in Australian soils. III. Residual organic and microbial biomass $\mathrm{C}$ and $\mathrm{N}$ from isotope-labeled legume material and soil organic matter, decomposing under field conditions. Aust. J. Soil Res. 23:603-611.

Mueller, T.G., N.J. Hartsock, T.S. Stombaugh, S.A. Shearer, P.L. Cornelius, and R.I. Barnhisel. 2003. Soil electrical conductivity map variability in limestone soils overlain by loess. Agron. J. 95: 496-507.

Müller, T., and H. Höper. 2004. Soil organic matter turnover as a function of the soil clay content: Consequences for model applications. Soil Biol. Biochem. 36:877-888.

Nelson, P.N., J.N. Ladd, and J.M. Oades. 1996. Decomposition of ${ }^{14} \mathrm{C}-$ labelled plant material in a salt affected soil. Soil Biol. Biochem. 28:433-441.

Oades, J.M. 1988. The retention of organic matter in soils. Biogeochemistry 5:35-70.

Oades, J.M., A.M. Vassallo, A.G. Waters, and M.A. Wilson. 1987. Characterization of organic matter in particle size and density fractions from Red-Brown Earth by solid-state 13C NMR. Aust. J. Soil Res. 25:71-82.

Olsson, P.A., and A. Johansen. 2000. Lipid and fatty acid composition of hyphae and spores of arbuscular mycorrhizal fungi at different growth stages. Mycol. Res. 104:429-434.

Rhoades, J.D., and D.L. Corwin. 1990. Soil electrical conductivity: Effects of soil properties and application to soil salinity appraisal. Commun. Soil Sci. Plant Anal. 21:837-860.

Ritchie, S.W., J.J. Hanaway, and G.O. Benson. 1997. How a corn plants develops. Spec. Publ. 48. Iowa State Univ. Coop. Ext. Serv., Ames, IO.

Saggar, S., A. Parshotam, G.P. Sparling, C.W. Feltham, and P.B.S. Hart. 1996. ${ }^{14} \mathrm{C}$-labelled ryegrass turnover and residence times in soils varying in clay content and mineralogy. Soil Biol. Biochem. 28: $1677-1686$.

SAS Institute. 1999. SAS/STAT software: Changes and enhancements through release 8.0. SAS Inst., Cary, NC.

Schepers, J.S., D.D. Francis, and M.T. Thompson. 1989. Simultaneous determination of total $\mathrm{C}$, total $\mathrm{N}$, and $15 \mathrm{~N}$ on soil and plant material. Commun. Soil Sci. Plant Anal. 20:949-959.

Schutter, M.E., and R.P. Dick. 2000. Comparison of fatty acid methyl ester (FAME) methods for characterizing microbial communities. Soil Sci. Soc. Am. J. 64:1659-1668.

Schutter, M.E., J.M. Sandeno, and R.P. Dick. 2001. Seasonal, soil type, and alternative management influences on microbial communities of vegetable cropping systems. Biol. Fertil. Soils 34:397-410.

Six, J., H. Bossuyt, S. Degryze, and K. Denef. 2004. A history of research on the linkage between (micro) aggregates, soil biota, and soil organic matter dynamics. Soil Tillage Res. 79:7-31.

Six, J., G. Guggenberg, K. Paustian, E.T. Elliot, and W. Zech. 2001. Sources and composition of soil organic matter free cations between and within aggregates. Eur. J. Soil Sci. 52:607-618.

Skene, T.M., J.O. Skjemstad, J.M. Oades, and P.J. Clarke. 1996. The influence of inorganic matrices on the decomposition of straw. Aust. J. Soil Res. 34:413-426.

Smith, J.L., and J.W. Doran. 1996. Measurement and use of pH and electrical conductivity for soil quality analysis. p. 169-186. In J.W Doran and A.J. Jones (ed.) Methods for assessing soil quality. ASA, CSSA, and SSSA, Madison, WI.

Stahl, P.D., and M.J. Klug. 1996. Characterization and differentiation of filamentous fungi based on fatty acid composition. Appl. Environ. Microbiol. 62:4136-4146.

van Veen, J.A., R. Merckx, and S.C. van de Geijn. 1989. Plant- and soil related controls of the flow of carbon from the roots through the soil microbial biomass. Plant Soil 115:179-188.

Wander, M.M., and G.A. Bollero. 1999. Soil quality assessment of tillage impacts in Illinois. Soil Sci. Soc. Am. J. 63:961-971.

White, D.C., W.M. Davis, J.S. Nickels, J.D. King, and R.J. Bobbie. 1979. Determination of the sedimentary microbial biomass by extractable lipid phosphate. Oecologia 40:51-62.

Wienhold, B.J., and R. Zhang. 2001. Use of electrical conductivity to estimate $\mathrm{N}$-mineralization contributions to crop $\mathrm{N}$ availability. Proc. XII World Fertil. Congr. of China International Exhibition Center. 1:390-397. Beijing, China. 